\title{
ANALISIS KESALAHAN PENGGUNAAN \\ KATA KETERANGAN BAHASA TIONGHOA \\ DALAM TUGAS VLOG MAHASISWA SASTRA TIONGHOA \\ UNIVERSITAS KRISTEN PETRA ANGKATAN 2015 \\ 彼得拉基督教大学中文系 2015 届学生在视频作业中 中文副词使用偏误分析
}

\author{
Yulia Yessica \\ Dwi Retnaning Untari, S.S, M.Hum \& Zhu Shuiqing, B.A., M.Pd. \\ Program Studi Sastra Tionghoa Universitas Kristen Petra, \\ Siwalankerto 121-131, Surabaya 60236 \\ E-mail: yyessica15@gmail.com
}

\begin{abstract}
ABSTRAK
Kesalahan berbahasa menunjukkan bahwa tujuan pengajaran bahasa belum tercapai secara maksimal, dan harus dikurangi sampai ke batas minimal, bahkan diusahakan dihilangkan sama sekali. Penelitian ini dilakukan untuk mengetahui bentuk kesalahan dan penyebab kesalahan penggunaan adverbia bahasa Tionghoa dalam tugas pembuatan $v \log$ mahasiswa Sastra Tionghoa Universitas Kristen Petra angkatan 2015. Penelitian ini menggunakan metode analisis tekstual. Data dalam penelitian ini yang adalah dokumen berupa 8 buah vlog yang dibuat oleh 17 mahasiswa angkatan 2015 Sastra Tionghoa Universitas Kristen Petra.

Dari keseluruhan 8 jenis kata keterangan bahasa Tionghoa, penulis menemukan adanya 5 jenis kata keterangan yang mengalami kesalahan pengunaan yaitu kata keterangan level, waktu, ruang lingkup, negasi, dan hubungan. Kesalahan yang terjadi berupa kesalahan penggunaan kata keterangan 太(tài), 正在 (zhèngzài), 就是 (jiùshì), 很 (hěn), 还是 (háishì), 只 zhī, 是否(shìfǒu) atau 是不是 (shìbúshì), 已经 (y̌̌jīng), dan 也 (yě).

Kesalahan penggunaan kata keterangan bahasa Tionghoa disebabkan oleh karena adanya pengaruh dari kata keterangan bahasa Indonesia, dimana bahasa Indonesia adalah bahasa ibu dari mahasiswa.
\end{abstract}

Kata Kunci : Kesalahan, Adverbia Bahasa Tionghoa, Adverbia Bahasa Indonesia 


\section{摘要}

在教学中出现语言偏误会导致无法达到教学目的, 因此语言偏误要尽 量减少, 甚至完全消除。如果不及时改正, 让学生成为习惯, 错误就会很难 消除。研究目的是找出彼得拉大学中文系 2015 届学生在视频作业中中文副 词使用偏误的种类和偏误主要原因。本研究笔者采用文本分析法研究法, 本 研究的材料是彼得拉大学中文系 2015 届学生的 8 个视频。制作视频的学生 由 17 位组成。

从 8 个中文副词种类，本研究出现了 5 种中文副词使用偏误; 程度副 词、时间副词、范围副词、否定副词与联系副词, 其中是: 太、正在、就 是、很、还是、只、是否或者是不是、已经、也。偏误发生的主要原因是因 为受到了印尼文(学生的母语)的影响。

关键词：偏误、中文副词、印尼文副词 


\section{PENDAHULUAN}

Kesalahan berbahasa menunjukkan bahwa tujuan pengajaran bahasa belum tercapai secara maksimal, dan harus dikurangi sampai ke batas minimal, bahkan diusahakan dihilangkan sama sekali. Apabila dibiarkan, kesalahan berbahasa akan membuat mahasiswa menjadi terbiasa, dan kesalahan tersebut akan terbawa terus menerus sehingga sulit diperbaiki atau dihilangkan.

Dalam mengikuti mata kuliah Bahasa Tionghoa IV, mahasiswa angkatan 2015 telah mendapatkan pembelajaran keterampilan berbahasa meliputi kemampuan membaca, mendengar, berbicara, dan linguistik bahasa Tionghoa. Di akhir mata kuliah Bahasa Tionghoa IV, mahasiswa program studi Sastra Tionghoa Universitas Kristen Petra angkatan 2015 diminta untuk membuat video blog (vlog) dalam bahasa Tionghoa untuk mengukur tingkat pemahaman dan keterampilan mahasiswa dalam berbahasa Tionghoa, khususnya dalam berbicara. Melalui tugas pembuatan vlog tersebut, mahasiswa dilatih untuk berbahasa Tionghoa sesuai dengan kaidah bahasa Tionghoa, mulai dari pelafalan hingga penggunaan sintaksis atau tata bahasa bahasa Tionghoa yang baik dan benar.

Menurut Zhang (2012), kata keterangan dalam bahasa Tionghoa memiliki peranan penting, pemakaiannya banyak dan beragam. Kata keterangan adalah salah satu kelompok kata yang sangat sering digunakan dalam berbahasa sehari-hari. Namun, penulis mendapati bahwa penelitian mengenai analisis kesalahan penggunaan kata keterangan oleh mahasiswa berbahasa ibu Bahasa Indonesia masih sangat sedikit. Selain itu, analisis kesalahan dengan menggunakan sumber data dalam bentuk dokumen yang dihasilkan sendiri oleh mahasiswa berbahasa Ibu Bahasa Indonesia belum pernah dilakukan. Oleh karena itu, penulis tertarik untuk melakukan penelitian mengenai kesalahan penggunaan kata keterangan bahasa Tionghoa dalam vlog mahasiswa angkatan 2015 Program Studi Sastra Tionghoa Universitas Kristen Petra.

Rumusan masalah dalam penelitian ini yaitu : Kesalahan kata keterangan apa saja yang terjadi dalam tugas vlog mahasiswa sastra Tionghoa Universitas Kristen Petra angkatan 2015? Apa faktor penyebab terjadinya kesalahan penggunaan kata keterangan dalam tugas vlog mahasiswa sastra Tionghoa Universitas Kristen Petra angkatan 2015? Tujuan penelitian ini adalah untuk menganalisis jenis kata keterangan yang terjadi dan penyebab terjadinya kesalahan penggunaan kata keterangan yang terdapat dalam tugas pembuatan $v$ log mahasiswa sastra Tionghoa Universitas Kristen Petra angkatan 2015.

\section{KAJIAN PUSTAKA}

\section{Kajian Tentang Analisis Kesalahan}

Menurut Zhu (2008), error adalah kesalahan sistematik yang muncul pada saat siswa telah menguasai tata bahasa suatu bahasa. Pada saat kesalahan itu muncul, siswa telah mampu menyusun berbagai kalimat lengkap, namun belum menguasai sistem tata bahasa tersebut dengan tepat dan menyeluruh. Selain itu, pengaruh tata bahasa dari bahasa ibu siswa seringkali menimbulkan kesalahan berbahasa pada siswa. 
Analisis kesalahan adalah sebuah kajian untuk menjelaskan kesalahan, dimulai dari pengumpulan data kesalahan, pengidentifikasian kesalahan, mendeskripsikan kesalahan, menjelaskan kesalahan, dan evaluasi kesalahan. Menurut Corder dalam Zhou (2012), analisis kesalahan memiliki tiga fungsi: Membuat pengajar memahami kondisi belajar siswa; Membuat peneliti memahami bagaimana siswa mempelajari suatu bahasa; Sebagai alat bagi siswa untuk menerapkan kaidah berbahasa yang benar.

Sesuai dengan definisi dan fungsinya, analisis kesalahan dalam penelitian ini berfungsi untuk menjelaskan kesalahan kata keterangan yang terjadi pada $v$ log mahasiswa angkatan 2015 Sastra Tionghoa Universitas Kristen Petra.

\section{Kajian Tentang Kelas Kata keterangan Bahasa Tionghoa}

Menurut Huang dan Liao (2016), kata keterangan dalam bahasa Tionghoa berfungsi sebagai keterangan ( 状 语 zhuàngyǔ) dalam kalimat, memodifikasi kata kerja, kata sifat, atau memodifikasi seluruh kalimat. Kata keterangan diletakkan di depan kata kerja atau kata sifat. Dalam Huang dan Liao (2016), jenis kata keterangan yang utama adalah ;

1. Menyatakan level atau tingkatan (表示程度 biăoshì chéngdù); contohnya : 很 hěn (sangat), 最 zuì (paling), 太 tài (terlalu), 非常 feeicháng (sangat), dsb.

2. Menyatakan ruang lingkup (表示范围 biăoshì fànwéi); contohnya : 都 dōu (semua), 全 quán (seluruh), 一起 yìqǐ (bersama-sama), 只 zhī (hanya), dsb.

3. Menyatakan waktu (表示时间 biăoshì shíjiān ); contohnya : 已经 y̌̉jīng (telah), 正在 zhèngzài (sedang), 立刻 lìkè (segera), 永 远 yǒngyuăn (selamanya), dsb.

4. Menyatakan negasi dan kepastian (表示否定、肯定 biăoshì fǒudìng kěndìng);

- menyatakan negasi, contohnya : 不 bù (tidak), 不必 búbì (tidak harus), 没有 méiyǒu (bukan), 不用 búyòng (tidak perlu), dsb.

- Menyatakan kepastian, contohnya : 必 bì (harus), 是 shì (ya), dsb.

5. Menyatakan tempat (表示外所 biăoshì wàisuǒ); contohnya: 四处 sìchù (di segala arah), 随处 suíchù (dimana-mana), dsb.

6. Menyatakan cara (表示方式 biăoshì fāngshì); contohnya : 特意 tèyì (khususnya), 忽然 hūrán (tiba-tiba), 连忙 liánmáng (buruburu), 悄悄 qiāoqiāo (diam-diam), dsb.

7. Menyatakan modalitas (表示语气 biăoshì yǔqì); contohnya：难怪 nánguài (tidak heran), 大约 dàyuē (kira-kira) 幸亏 xìngkū̄ (untungnya), 明明 míngmíng (jelas-jelas), dsb.

8. Menyatakan hubungan (表示联系 biăoshì liánxì); contohnya : 便 biàn (sambil), 又 yòu (lagi, juga), 却 què (tetapi) dsb. 


\section{METODE PENELITIAN}

Jenis penelitian yang akan dilakukan oleh penulis adalah penelitian dengan metode analisis tekstual. Dalam hal ini, metode analisis tekstual akan digunakan untuk mendeskripsikan kesalahan penggunaan kata keterangan bahasa Tionghoa dalam vlog mahasiswa angkatan 2015 sastra Tionghoa Universitas Kristen Petra.

Sumber data dalam penelitian ini adalah 8 buah vlog mahasiswa angkatan 2015 Sastra Tionghoa Universitas Kristen Petra. Setiap vlog yang ada adalah vlog yang dibuat oleh 17 mahasiswa yang terbagi dalam delapan kelompok. Dalam melakukan penelitian ini, penulis telah mendapatkan persetujuan dari seluruh mahasiswa yang menjadi subjek penelitian dan dosen pengampu mata kuliah Bahasa Tionghoa IV. Tujuh belas mahasiswa yang menjadi sumber data adalah jumlah keseluruhan mahasiswa yang mengikuti kelas Bahasa Tionghoa IV. Teknik pengumpulan data yang digunakan dalam penelitian ini adalah dokumen berupa video. Data berupa video blog mahasiswa didapatkan melalui dosen pengampu mata kuliah Bahasa Tionghoa IV.

\section{ANALISIS}

Berdasarkan hasil pengelompokan dan pengkodean data, penulis menemukan bahwa dari 8 vlog mahasiswa, hanya 6 vlog yang mengandung kesalahan kata keterangan, sedangkan dalam 2 vlog lainnya tidak terdapat kesalahan penggunaan kata keterangan bahasa Tionghoa.

Dari keseluruhan 8 jenis kata keterangan bahasa Tionghoa, penulis menemukan adanya 5 jenis kata keterangan yang mengalami kesalahan pengunaan kata keterangan yaitu kata keterangan level, kata keterangan waktu, kata keterangan ruang lingkup, kata keterangan negasi, dan kata keterangan hubungan.

\section{Analisis kesalahan penggunaan kata keterangan “太 tài”}

Pada kalimat yang pertama, kesalahan yang muncul adalah sebagai berikut: “对啊, 老师们太创意了吧 (Duì a, lăoshīmen tài chuàngyìle ba)”. “老师 lăoshī” adalah subjek kalimat, “太 tài” sebagai kata keterangan, “创意 chuàngyì” sebagai kata benda. Apabila diterjemahkan dalam bahasa Indonesia, kalimat tersebut menjadi: "Benar, guru kita sangat kreatif." Dalam bahasa Indonesia, "kreatif" adalah kata sifat. Kata keterangan "太” memiliki arti "melebih-lebihkan" atau "sangat". Makna yang hendak penutur sampaikan dalam kalimat di atas adalah tingkatan atau level "kreativitas" yang tinggi. Dalam hal ini, kata “太” tidak dapat langsung digunakan bersamaan dengan kata “创意”. Kata “有 yǒu” harus diletakkan di antara “太” dan “创意”, untuk menyatakan bahwa guru tersebut adalah orang yang "sangat kreatif".

Menurut Xu (2005), “太” dapat digunakan bersamaan dengan “有 + kata benda ", membentuk struktur kata kerja-objek (动宾). Susunannya dalam kalimat adalah “太” + 有 + kata benda”. Dalam hal ini, “有” + “创意” membentuk struktur kata kerja-objek (动宾 dòngbīn) yang artinya“memiliki kreatifitas”. Dalam kalimat ini, kesalahan penggunaan kata keterangan disebabkan karena penutur terpengaruh dari bahasa Indonesia "kreatif", 
Pada kalimat yang kedua, penutur menyatakan jawaban dari pertanyaan orang lain. Pertanyaan yang diajukan adalah : “很热吗 (hěnrèma)?” (apakah panas?) penutur menjawab dengan “太热 tàirè”. Maksud dari kalimat yang diucapkan penutur adalah"sangat panas", untuk menyatakan tingginya tingkat atau level "panas". Dalam bahasa Tionghoa, kata “很 hěn” dan “太 tài” keduanya dapat digunakan untuk menyatakan tingkatan atau level, namun “太” juga memiliki fungsi untuk menyatakan ketidakpuasan akan tingkatan yang tinggi tersebut (Xiao, 2018). Berdasarkan makna yang hendak disampaikan penutur, dalam kalimat ini, penutur tidak sedang menyatakan ketidakpuasan terhadap cuaca yang panas, melainkan hanya memberikan jawaban atas pertanyaan yang diajukan sebelumnya.

Pada kalimat yang ketiga, kesalahan terjadi dalam kalimat berikut: “甜啊, 我不喜欢 (Tián a, wǒ bù xǐhuān)". Bila diterjemahkan dalam bahasa Indonesia, kalimat yang mengandung kesalahan kata keterangan ini menjadi "manis, aku tidak suka." Sedangkan, makna yang hendak disampaikan penutur adalah "Terlalu manis, aku tidak suka". Dalam kalimat ini, seharusnya kata keterangan “太” ditambahkan untuk menyatakan bahwa penutur tidak menyukai benda tersebut karena rasanya yang 'terlalu' manis. Dalam hal ini, “太” perlu ditambahkan untuk menyatakan ketidakpuasan terhadap makanan tertentu. Apabila tidak ditambah dengan kata “太”, makna kalimat yang hendak dinyatakan penutur menjadi berubah dan tidak sesuai dengan kaidah penggunaan kata keterangan “太”.

\section{Analisis kesalahan penggunaan kata keterangan "正在 zhèngzài"}

Pada kalimat yang pertama, kesalahan yang muncul adalah sebagai berikut : 对了, 我们现在正在 Tretes, 是昨天晚上从泗水出发的 (Duile, wǒmen xiànzài zhèngzài Tretes, shì zuótiān wănshàng cóng sìshuǐ chūfā de). Pada kalimat kedua, penutur juga melakukan kesalahan serupa; “终于到了, 我们现在正在 Jodipan City (Zhōngyú dàole, wǒmen xiànzài zhèngzài Jodipan City.)" Pada kedua kalimat tersebut, penutur sedang menyatakan posisi atau lokasi mereka, bukan sedang menyatakan kondisi kegiatan yang sedang berlangsung. Jadi, penggunaan 正在 dalam dua kalimat tersebut tidaklah tepat. Selain itu, kata 在 dalam frasa “在 Jodipan City" dan “在 Tretes" adalah kata kerja, dan tidak dapat diletakkan berdampingan dengan 正. Menurut Yang Jizhou (2012), ada beberapa kata kerja yang tidak dapat digunakan bersamaan dengan 正, 在 dan 正在, yaitu “是 shì、在 zài、来 lái、去 qù" dan lain sebagainya. Sehingga, saat 在 berfungsi sebagai kata kerja, 在 tidak dapat digunakan bersamaan dengan kata keterangan waktu “正”.

Menurut Yang Jizhou（2012）, “正在” menyatakan keadaan yang sedang terjadi dalam kurun waktu tertentu. “正在” menyatakan suatu kegiatan yang berlangsung terus-menerus. Sedangkan, kalimat di atas tidak sedang menyatakan keberlangsungan suatu kegiatan. Susunannya 正在 dalam kalimat adalah : Subjek + 正在 + kata kerja + objek (Miao, 2007). Dalam hal ini, penutur hendak menyatakan lokasi mereka, bila kalimat pertama diterjemahkan dalam Bahasa Indonesia menjadi "Benar, sekarang kami sedang berada di Tretes, kemarin malam berangkat dari Surabaya." 
Sedangkan bila kalimat kedua diterjemahkan dalam Bahasa Indonesia menjadi: "Akhirnya sampai, kami sekarang ada di Jodipan City". Penulis menyimpulkan bahwa kesalahan penggunaan “正在” dalam dua kalimat tersebut disebabkan oleh kurangnya pemahaman mahasiswa terhadap perbedaan penggunaan kata keterangan “正在” dan “在”.

Selain itu, dalam bahasa Tionghoa modern, kata “在” dapat berfungsi sebagai kata keterangan yang menyatakan suatu kegiatan sedang berlangsung, dan juga dapat berfungsi sebagai kata depan "di”. Sedangkan dalam bahasa Indonesia, kata sedang memiliki fungsi untuk menjelaskan proses "masih dalam melakukan sesuatu (Alwi, 2011). Dalam bahasa Indonesia, kata sedang tidak dapat diterjemahkan sebagai preposisi "di". Berdasarkan uraian di atas, penulis menyimpulkan bahwa penutur terpengaruh keterangan waktu "sedang" dalam bahasa Indonesia, sehingga penutur salah membedakan fungsi kata 在 sebagai keterangan dan sebagai kata hubung dalam bahasa Tionghoa.

\section{Analisis kesalahan penggunaan kata keterangan “就是 jiùshì”}

Setelah melakukan pengkodean dan pengelompokan, penulis mendapatkan adanya enam kesalahan penggunaan kata keterangan “就是 jiùshì”. Pada kalimat yang pertama dan kedua, penutur menggunakan kata keterangan “就是” di depan kata kerja. Menurut Zhōngguó Huáwén Jiàoyù (2008), “就是” dapat digunakan untuk menekankan kalimat afirmatif, dalam kalimat dalam susunannya adalah sebagai berikut: “就是” + kata kerja / kata sifat / kata benda”, untuk menyatakan kemauan atau keinginan yang kuat dan sulit diubah. Kesalahan yang dilakukan penutur adalah sebagai berikut: “Jodipan City 就是在 Malang 的中间 (Jodipan City jiùshì zài Malang de zhōngjiān” dan “是的, 很容易找到, 就是靠近 Brantas 河流 "Shì de, hěn róngyì zhăodào, jiùshì kàojìn Brantas héliú)"

Kata“在”dan“靠近”keduanya adalah kata kerja, dan dalam hal ini, keduanya tidak sedang memberikan menekankan dalam kalimat. Penutur hendak menyatakan suatu lokasi, bukan menyatakan keinginan dan pemikiran yang kuat. Jadi, penggunaan kata keterangan 就是 pada kedua kalimat di atas kurang tepat. Pembetulan kalimat di atas menjadi : Jodipan City 就在 Malang 的中间”; dan “是 的, 很容易找到, 就靠近 Brantas 河流”.

Pada kalimat ketiga, penutur menyatakan tanggapan dari penutur lain. Adapun percakapan yang dilakukan penutur dalam $v \log$ adalah sebagai berikut.

A: 你们要买吗? (Nǐmen yāomăi ma?)

B: 德尼 (C) 要买。(Dé ní (C) yāomăi.)

$\mathrm{C}$ : 就是我。(Jiùshì wǒ.)

Dalam percakapan di atas, penutur (C) memberikan tanggapan atas pernyataan orang lain yaitu “德尼 (C) 要买”, penutur menjawab “就是我” Bila diterjemahkan dalam bahasa Indonesia, maksud yang hendak penutur sampaikan adalah"saya yang mau beli". Dalam hal ini, penutur hendak memberikan penekanan pada kata “我 wǒ/ saya”.

Pada kalimat ketiga, kesalahan penggunaan kata keterangan “就是” disebabkan oleh adanya pengaruh dari kata "yang" dalam bahasa Indonesia. Menurut Alwi (2011), "yang” memiliki fungsi untuk menjelaskan dan menegaskan 
kata yang ada di depanya. Kesalahan penggunaan kata keterangan bahasa Tionghoa terjadi karena penutur langsung menterjemahkan kata “yang” menjadi “就是”. Kalimat pembetulannya seharusnya menjadi “我要买 (Wǒ yāomăi)”.

Pada kalimat keempat, kesalahan yang terjadi adalah : “这就是甜甜的牛里 脊肉(Zhè jiùshì tián tián de niú lǐjí ròu)”. Kata “甜甜 tián tián” disini berfungsi sebagai kata sifat. Menurut Zhōngguó Huáwén Jiàoyù (2008), saat diikuti dengan kata sifat, “就是” menyatakan kemauan atau keinginan yang kuat dan sulit diubah. Saat diikuti dengan kata kerja atau kata sifat, “就是” memberikan penekanan pada suatu kondisi, atau memberikan sanggahan.

Kalimat keempat bila diterjemahkan dalam bahasa Indonesia menjadi "Ini adalah daging empal yang manis." Disini, penutur hendak memberikan penjelasan mengenai "benda ini". Penutur tidak sedang memberikan sanggahan maupun menyatakan keinginan yang kuat. Jadi, penggunaan “就是” dalam kalimat di atas kuranglah tepat. Kalimat pembetulannya menjadi : “这是甜甜的 empal (Zhè shì tián tián de empal)".

Pada kalimat kelima, penutur mengatakan：“这就是印尼的饼干 (Zhè jiùshì yìnní de bǐnggān)" dalam bahasa Indonesia, menjadi "Ini adalah kerupuk Indonesia." Kata “印尼的饼干(yìnní de bǐnggān)” atau "kerupuk Indonesia” adalah frasa nomina. Menurut Zhōngguó Huáwén Jiàoyù (2008), saat “就是” digunakan bersama dengan kata benda, “就是 berfungsi untuk menyatakan batasan atau ruang lingkup yang jelas. Dalam kalimat ini, makna yang penutur hendak sampaikan sama dengan kalimat keempat, yakni menjelaskan suatu benda tertentu. Penutur tidak sedang menyatakan batasan atau ruang lingkup. Pembetulan dari kalimat di atas adalah “这是印尼的饼干(Zhè jiùshì yìnní de bǐnggān)”.

Pada kalimat keenam, penutur mengatakan : “就是难说呗, 都很好吃 (Jiùshì nánshuō bei, dōu hěn hào chī)". Disini, “难说 (nánshuō)” adalah kata kerja. Saat “就是” digunakan bersama dengan kata kerja, “就是” memiliki fungsi untuk menyatakan kemauan atau keinginan yang kuat dan sulit diubah. Namun dalam kalimat tersebut, penutur tidak sedang menekankan kemauan atau keinginan yang kuat dan sulit diubah. Maksud yang ingin disampaikan penutur adalah "susah memutuskanya, semuanya enak”. Kalimat pembetulannya menjadi “很难决定, 都很好吃 (Hěn nán juédìng, dōu hěn hào chī)”

\section{Analisis kesalahan penggunaan kata keterangan “很 hěn”}

Penulis mendapatkan adanya dua kesalahan penggunaan kata keterangan “很 hěn”. Kesalahan yang dilakukan oleh penutur sebagai berikut:“我 已经 漂亮 了吗?” (Wǒ yǐjīng piàoliangle ma?)” dan “不要, 我已经 漂亮 啊 (Bùyào, wǒ y̌̌jīng piàoliang a)". Kedua kalimat tersebut apabila diterjemahkan dalam bahasa Indonesia, kalimat ini menjadi: Apakah aku sudah cantik? "; dan "tidak mau, aku sudah cantik". Dalam sintaksis bahasa Tionghoa, kata keterangan “很” kadang kala tidak selalu memiliki arti "sangat", dan hanya berfungsi sebagai komponen gramatikal untuk menyempurnakan struktur kalimat. Menurut Liu (2013), kata keterangan “很” harus ditambahkan di antara kata benda dan kata sifat (kata benda + 很 + kata sifat) untuk menyempurnakan struktur kalimat. Kalimat bahasa 
Tionghoa di atas menjadi salah karena kurangnya kata keterangan level 很 (sangat), yang seharusnya diletakkan sebelum kata sifat 漂亮 piàoliang (cantik).

Kalimat pembetulan dari kedua kalimat di atas adalah: “我已经很漂亮啊 Wǒ yỉjīng hěn piàoliang a" Apabila kalimat pembetulan ini diterjemahkan kembali ke dalam bahasa Indonesia, kalimat tersebut memiliki dua bentuk arti, yaitu: "Saya sudah cantik."; dan "Saya sudah sangat cantik." Dalam sintaksis bahasa Indonesia, kata "sangat" hanya berfungsi sebagai untuk menyatakan level saja. Sedangkan dalam bahasa Tionghoa, selain untuk menyatakan level "sangat", kata keterangan level 很 juga berfungsi sebagai suatu komponen gramatika. Menurut Liu Xun (2013), saat 很 berfungsi sebagai komponen gramatika, kata 很 mengalami pelemahan arti, sehingga tidak lagi memiliki arti "sangat". Penulis menyimpulkan bahwa kesalahan pada kalimat di atas disebabkan karena adanya perbedaan fungsi dan kegunaan kata “很” dalam bahasa Tionghoa dan kata “sangat" dalam Bahasa Indonesia. Selain itu, kesalahan juga dapat terjadi akibat kurangnya pengetahuan mahasiswa mengenai penggunaan kata keterangan level “很” dalam kaidah sintaksis bahasa Tionghoa.

\section{Analisis kesalahan penggunaan kata keterangan “还是 háishi”}

Pada kalimat yang mengandung kesalahan penggunaan kata keterangan“还 是 háishi”, kesalahan yang dilakukan oleh penutur adalah sebagai berikut: “虽然 来这里旅行的人很多, 但是当地人还是做商业 (Suīrán lái zhèlǐ lüxxíng de rén hěnduō, dànshì dāngdì rén háishì zuò shāngyè)" Apabila diterjemahkan dalam bahasa Indonesia, maka kalimat di atas menjadi; "Meskipun orang yang berlibur ke sini banyak, tetapi penduduk lokal masih membuka usaha." Kata "masih" dalam kalimat tersebut berfungsi untuk memodifikasi kata kerja "membuka usaha".

Adapun kesalahan yang dilakukan penutur adalah kesalahan penggunaan kata 还是 (masih) untuk menjelaskan bahwa penduduk lokal masih membuka usaha. Selain kesalahan penggunaan kata keterangan waktu. Menurut Lin Ting Xu (2011) Kata keterangan waktu 还是 dalam bahasa Tionghoa biasanya digunakan untuk menyatakan keadaan yang tetap sama 还是 menyatakan bahwa bagaimanapun kondisinya suatu hal terjadi, atau akan terjadi. 还是 biasanya digunakan dalam rumusan berikut:

$$
\cdots \cdots \text {, (但是 } / \text { 可是 tetapi })+ \text { Subjek }+ \text { 还是 }+ \text { Frasa Verba }
$$

Menurut Yi Ying (2011), kata keterangan 还 juga dapat digunakan untuk menyatakan bahwa suatu kegiatan atau suatu keadaan yang masih terus terjadi hingga saat ini (kontinuitas). Saat menyatakan kontinuitas, kata 还 biasanya diikuti dengan kata kerja “在 zài (sedang)”, untuk menekankan keadaan sedang terjadi dan masih berkelanjutan. Kata 还在 bila diterjemahkan dalam bahasa Indonesia menjadi "masih sedang".

Dalam konteks kalimat di atas, seharusnya menggunakan kata keterangan waktu 还在, untuk menyatakan kontinuitas penduduk lokal dalam membuka usaha. sehingga, dalam kalimat pembetulannya, “当地人 (penduduk lokal)” sebagai subjek, “还在 (masih)” sebagai kata keterangan waktu, dan “做生意 (membuka usaha)" sebagai frasa verba. Berdasarkan uraian di atas, dapat disimpulkan bahwa 
kesalahan penggunaan kata keterangan diatas disebabkan karena adanya keberagaman dan perbedaan makna dan fungsi kata"masih" dalam Bahasa Tionghoa. Penutur yang berbahasa ibu bahasa Indonesia masih belum dapat membedakan fungsi dan penggunaan kata keterangan 还(在) dan 还是, sedangkan dalam bahasa Indonesia, makna kata "masih" sangat terbatas dan tidak beragam.

\section{Analisis kesalahan penggunaan kata keterangan“只 zhī”}

Pada kalimat, kesalahan yang dilakukan oleh penutur adalah sebagai berikut: “好嘛, 我们 的 vlog 只到 这里 (Hăo ma, wǒmen de vlog zhǐ dào zhèlǐ)” Apabila diterjemahkan dalam bahasa Indonesia, maka kalimat di atas menjadi "baiklah, vlog kami sampai di sini saja”. Dalam kaidah tata Bahasa Tionghoa, kata “只 zhī” termasuk dalam kata keterangan yang menyatakan ruang lingkup, sedangkan kata “就 jiù” dapat menyatakan ruang lingkup dan waktu. Ketika kata keterangan 就 berfungsi untuk menyatakan ruang lingkup, 就 memiliki arti yang sama dengan 只 yaitu "hanya".

Menurut Liu Xun (2013), kata keterangan 只 biasanya diletakkan sebelum kata kerja, atau sebelum kata kerja penjelas atau kata kerja bantu (auxiliary verb) seperti 会(bisa/dapat) atau 能(bisa/dapat). Penggunaan kata 只 dalam kalimat dirumuskan sebagai berikut: “只 + Verb” atau “只 + 会 / 能 + Verb”.

Saat kata keterangan 就 menyatakan waktu, kata 就 tidak dapat digantikan dengan kata 只, karena memiliki makna yang berbeda (Huang dan Liao, 2016). Dalam konteks kalimat di atas, kata 就 menerangkan waktu, yaitu bahwa vlog tersebut akan segera berakhir. Kalimat tersebut seharusnya menjadi: “好嘛, 我们 的 $v \log$ 就到 这里 (Hăo ma, wǒmen de vlog jiù dào zhèlǐ)”. Penulis menyimpulkan bahwa kesalahan pada kalimat ini terjadi karena penutur kurang memahami kaidah penggunaan kata keterangan 就.

\section{Analisis kesalahan penggunaan kata keterangan “是否 shìfǒu” atau “是不是 shìbúshì"}

Kesalahan yang dilakukan oleh penutur adalah sebagai berikut. “很多人 想 Hello Panda 和 Koala's March 是一样 吗? (Hěnduō rén xiăng Hello Panda hé Koala's March shì yīyàng ma)". Bila diterjemahkan dalam Bahasa Indonesia, kalimat tersebut menjadi : "Banyak orang berpikir apakah Hello Panda dan Koala's March itu sama." Adapun kalimat di atas menjadi salah karena kalimat yang diucapkan penutur merupakan kalimat berita dan kalimat tidak langsung, namun menggunakan kata tanya “吗” (-kah).

Menurut Yang Jizhou (2012), di akhir kalimat pernyataan, kata tanya “吗” digunakan untuk menyatakan pertanyaan yang membutuhkan jawaban "ya" atau "tidak". Dalam konteks kalimat di atas, penutur hendak menyatakan bahwa ada banyak orang yang berpikir apakah Hello Panda dan Koala's March itu sama. Penutur hendak menyatakan suatu pernyataan, bukan sebuah pertanyaan yang memerlukan jawaban "ya" atau "tidak". Oleh karena itu, pembetulan dari kalimat tersebut menjadi: “很多人想 Hello Panda 和 Koala's March 是否一样” atau “很多人想 Hello Panda 和 Koala's March 是不是一样。” Kata keterangan 是 
否 atau 是不是 bila diartikan dalam bahasa Indonesia memiliki arti “apakah”. 是 否 dan 是不是, keduanya juga digunakan dalam kalimat pernyataan.

\section{Analisis kesalahan penggunaan kata keterangan “已经 yǐjīng”}

Pada kalimat pertama, kalimat yang diucapkan penutur adalah: “不要了， 我刚才说我在减肥 (Bùyàole, wǒ gāngcái shuō wǒ zài jiănféi)”. Apabila diterjemahkan dalam bahasa Indonesia menjadi "Tidak mau, aku barusan sudah bilang bahwa aku sedang diet". Makna kalimat yang hendak penutur sampaikan adalah; 'sebelum' ia mengatakan hal ini, ia 'telah' berkata bahwa ia sedang diet".

Menurut Zhang Kai (2010), “已经 yìjīng” menyatakan bahwa suatu keadaan atau perbuatan telah terjadi sebelum seseorang mengatakan suatu hal, dan saat pembicaraan berlangsung, hasil dari keadaan tersebut masih ada. Rumusan 已 经 dalam kalimat adalah : “已经 + frasa verba + 了(le)”. Kalimat di atas kurang tepat karena kurangnya penggunaan kata keterangan 已经. Maka pembetulan kalimat di atas adalah 不要了, 我刚才已经说我在减肥(Bùyàole, wǒ gāngcái yỉjīng shuō wǒ zài jiănféi)".

Pada kalimat yang kedua, kesalahan yang dilakukan penutur sebagai berikut: “这个食物已经在印尼很普及了(Zhège shíwù yỉjīng zài yìnní hěn pǔjíle)” Bila diterjemahkan dalam Bahasa Indonesia, kalimat tersebut menjadi "Makanan ini sangat umum ditemui di Indonesia". Makna kalimat yang ingin disampaikan oleh penutur adalah makanan ini umum atau sering dijumpai, sehingga penggunaan kata keterangan 已经 dalam kalimat ini kurang tepat. 已经 digunakan untuk menyatakan bahwa sebelum pembicaraan tersebut berlangsung, suatu hal atau kondisi telah terjadi sebelumnya, namun dalam kalimat di atas, saat penutur menyampaikan kalimatnya, keadaan atau kondisi "makanan (yang umum/sering dijumpai)" tersebut tidak berubah dan tetap sama, sehingga penggunakan kata “已经” dalam kalimat tersebut menjadi tidak tepat. Pembetulan dari kalimat di atas menjadi : “这 个食物在印尼很常见(Zhège shíwù zài yìnní hěn chángjiàn)”.

\section{Analisis kesalahan penggunaan kata keterangan "也 yě"}

Setelah melakukan pengkodean dan pengelompokan, penulis mendapatkan adanya satu kesalahan penggunaan kata keterangan “也 yě”. Menurut Miao (2007), kata keterangan “也” dapat digunakan secara tunggal atau sebagai penghubung, dan berfungsi untuk menyatakan beberapa keadaan yang berlangsung di waktu yang sama. Rumusan kata keterangan “也” dalam kalimat adalah sebagai berikut: subjek + “也” + kata kerja atau frasa verba, dan subjek + “也”( + kata keterangan ) + kata sifat.

Dalam kalimat yang diucapkan penutur, kesalahan yang terjadi adalah sebagai berikut: : “也还有国家的国旗 (Yě hái yǒu guójiā de guóqí)” Apabila diterjaemahkan dalam bahasa Indonesia, kalimat tersebut menjadi : "juga ada bendera negara”. Dalam kalimat ini, kata keterangan “也” tidak dapat diletakkan di depan kata “还有”, karena tidak sesuai dengan kaidah penggunaan kata keterangan “也”. Pembetulan dari kalimat di atas adalah “还有国家的国旗 (Hái yǒu guójiā de guóqí)" 
Dalam Bahasa Indoneisa, baik “也” dan “还有 hái yǒu” sama-sama diartikan sebagai“juga". Pada kalimat di atas, penutur hendak menyatakan bahwa "(disini) juga ada bendera negara." Berdasarkan uraian di atas, penulis menyimpulkan bahwa kesalahan terjadi akibat terpengaruh kata keterangan bahasa Indonesia "juga".

\section{KESIMPULAN}

Pada tugas vlog mahasiswa Sastra Tionghoa Universitas Kristen Petra angkatan 2015, dari keseluruhan 8 jenis kata keterangan bahasa Tionghoa, penulis menemukan adanya 5 jenis kata keterangan yang mengalami kesalahan pengunaan kata keterangan yaitu kata keterangan level, kata keterangan waktu, kata keterangan ruang lingkup, kata keterangan negasi, dan kata keterangan hubungan. Kesalahan yang terjadi berupa kesalahan penggunaan kata keterangan 太(tài), 正在 (zhèngzài), 就是 (jiùshì), 很 (hěn), 还是 (háishì), 只(zhī), 是否(shìfǒu) atau 是不是 (shìbúshì), 已经 (y̌̉jīng), dan 也 (yě).

Faktor penyebab kesalahan penggunaan kata keterangan yaitu disebabkan oleh adanya perbedaan fungsi dan cara penggunaan kata keterangan dalam bahasa Tionghoa dan bahasa Indonesia yang membuat mahasiswa terpengaruh oleh kaidah penggunaan kata keterangan dalam bahasa Indonesia. Dari uraian di atas, dapat disimpulkan bahwa kesalahan penggunaan kata keterangan bahasa Tionghoa disebabkan oleh karena adanya pengaruh dari kata keterangan bahasa Indonesia, dimana bahasa Indonesia adalah bahasa ibu dari mahasiswa.

Untuk menghindari kesalahan penggunaan kata keterangan Bahasa Tionghoa, mahasiswa memerlukan banyak latihan dan pendalaman materi mengenai kata keterangan bahasa Tionghoa, beserta perbedaan cara penggunaan dan padanan katanya dalam bahasa Indonesia, agar mahasiswa dapat menggunakan kata keterangan bahasa Tionghoa sesuai dengan kaidah dan cara penggunaan yang benar.

\section{DAFTAR PUSTAKA}

Alwi, Hasan. (2011). Kamus Besar Bahasa Indonesia. Jakarta: Gramedia Pustaka Utama.

Huang, B. \& Liao, X.(2016). Xiàndài Hànyǔ. Beijing: Higher Education Press.

Lin, Ting Xu. (2011). "Hai" and "Haishi": Different Functions when Expressing Continuity (Biăoshì Chíxù Yì de "Hái” yǔ "Háishì"). Taiwan: Taiwan Normal University.

Liu, Xun. (2013). Xīn Shíyòng Hànyǔ Kèběn [New Practical Chinese Reader Textbook 1]. Beijing: Beijing Language and Culture UP.

Miao, Dongxia (2007). HSK Kăo Qián Qiánghuà: Gāoděng. Beijing: Peking University Press.

Qi, Huyang. (2014). Xiàndài Hànyǔ Xūcí Yánjiū yǔ Duìwài Hànyǔ Jiàoxué. Shanghai: Fudan University Press.

Xiao, Yali. (2018). Xiàndài Yǔwén (Yǔyán Yánjiū): Găntàn Jù Zhōng "tài" hé "zhèn" yǔ Yǔqì Cí Gòng Xiàn de Chāyì Fēnxī. Guizhou: Kaili College of Humanities 
Xu, Jianhong. (2005). Chéngdù fùcí "hěn" yǔ "tài" de yòngfă biànxī. Journal of Liaoning University (Philosophy and Social Sciences). 33(2). Retrieved July 2, 2018 from http://www.cnki.net.

Yang, Jiayin. (2013, November). Nǐ Liăojiě “Jiù” de Yòngfă ma. Kŏngž̌ Xuéyuàn21(6). Retrieved May 5, 2018 from http://www.confucius-institutemagazine.com

Yang, Jiezhou. (2012), Hànyǔ jiàochéng, dì ȳ̄ cè shàng (xiūdìng běn). Beijing: Beijing Language and Culture University Press.

Yi Ying. (2011, Oktober). Perbandingan Karakteristik Dan Fungsi Kata Keterangan Bahasa Mandarin Dan Bahasa Indonesia. Jurnal Humaniora 2(2), 944-949.

Zhang, Jielin (2012). Hànyǔ Chéngdù Fùcí Piān Wù Fēnxī. China Academic Journal Electronic Publishing House. H(146), Retrieved April 15, 2008 from http://www.cnki.net

Zhang, Kai. (2010). New Practical Chinese Reader 3 (Xīn Shíyòng Hànyǔ Kèběn 3) : Beijing: Beijing Language and Culture University Press.

Zhang, Yisheng. (2014). Xiàndài Hànyǔ Fùcí Yánjiū. Shanghai: Shāngwù yìn shūguăn.

Zhōngguo Huawen Jiaoyu. (2008). “Jiùshì" de yòngfă. Retrieved May 20, 2018 from http://www.hwjyw.com

Zhou, Xiaobing. (2012). Wàiguó Rén Xué Hànyǔ Yǔfă Piān Wù Yánjiū. Beijing: Peking University Press.

Zhu, Qizhi. (2008). Yǔfă Piān Wù Lèibié de Kăochá. Beijing : Peking University Press. 